\title{
Cytological Study on Sterility in Salvinia auriculata Aublet with a Bearing on Its Reproductive Mechanism
}

\author{
D. S. Loyal and R. K. Grewal
}

Botany Department, Panjab University, Chandigarh, India

Received October 28, 1965

\section{Introduction}

From a perusal of earlier literature and the beginning of cytological studies on heterosporous ferns in this laboratory (Loyal 1958, 1962, Mehra and Loyal 1959, and Loyal and Grewal 1964) it became immediately obvious that polyploidy and inviable spores occur in a large number of species. However, the absence of cytological data with modern techniques has been a major limiting factor in a correct understanding of their reproductive mechanism in the absence of functional spores. The above situation has been recorded in Salvinia auriculata Aublet by Mahabale and D'Mello (1952) and Bonnet (1955). The cause of aberrant meiosis in this species remained unknown and its reproductive mechanism, as judged from the present data, was erroneously interpreted to be apogamous (cf. Mehabale and D'Mello, l.c.). The present cytological study provides a definite clue to the above probelm and morphological results will appear separately.

The species occurs in wild state in tropical America distributed from Cuba to Brazil. Besides its being under cultivation in several botanical gardens of the Indian subcontinent; it is reported outside as well.

\section{Material and methods}

The material was collected from several stations in India such as Hoshiarpur (Punjab), Ajmer and Alwer (Rajasthan), and Gorakhpur (Uttar Pradesh). Later, living material was obtained from Rhodesia, S. Africa through the courtesy of Dr. D. S. Mitchell.

Meiosis was studied solely from acetocarmine squashes. Somatic chromosome counts were made from young leaf tips. For the developmental stages of mega- and microsporangia fixations were made in $2 \mathrm{BD}$ LaCour and F.A.A. Sections were cut $10-12 \mu$ thick and stained with safranin-fast green combination.

\section{Observations}

The plants of different populations were morphologically identical and the developmental stages of the mega- and microsporangia leading to complete sterility was uniformly observed.

Megasporangia and megasporogenesis: A fully mature megasporocarp, which is smaller than the microsporocarp, possesses 30-40 megasporangia borne on short stalks. A detailed analysis of 100 fully developed megasporocarps showed 62 per cent with completely abortive megasporangia that lack contents. The rest of 38 per cent contained megaspores which as will be shown later, are non-functional due to aberrant meiosis. The maximum number of 
functional megasporangia is 4 per sporocarp. Only one megaspore is organized in a sporangium. It is pertinent to point out that in diploid sexual Salvinia natans not even one megasporocarp was found with abortive sporangia (unpublished data).

The development of megasporangium follows the leptosporangiate pattern. The sporangial initials appear as superficial cells and are large in size with prominent nuclei and denser cytoplasm (Fig. 1). Each initial after having divided twice forms two primary stalk cells and the apical cell cuts off 3 primary wall cells, 3 tapetal cells and a central cell (Figs. 2-4). The latter undergoes three mitotic divisions and form eight-celled archesporium (Figs.

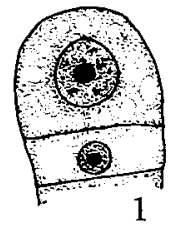

1
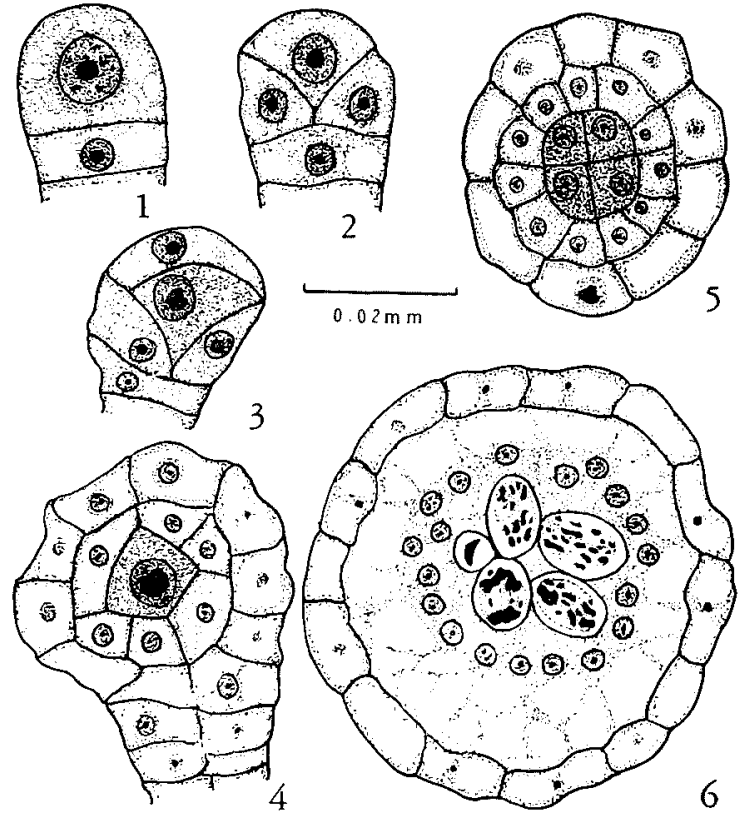

6

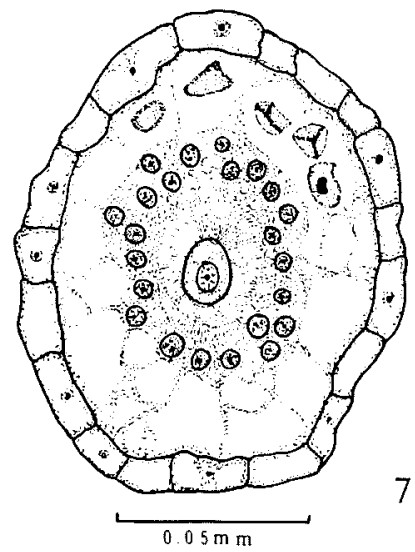

Figs. 1-7. 1, L.S. megasporangial initial. 2, L.S. megasporangium showing first and second wall cells cut off. 3, L.S. megasporangium with three wall cells surrounding a single-celled

archesporium. 4, Archesporium surrounded by tapetal cells. 5, T.S. megasporangium with eight-celled archesporium, four being seen in a section. 6 , spore mother cells in a megasporangium showing irregular meiosis. 7, T.S. megasporangium with a functional megaspore and the nonfunctional ones towards the periphery.

$5,6)$ whose cells behave as eight spore mother cells. The course of meiosis, as will be described in the subsequent pages, is highly abnormal owing to pentaploid nature of the species.

The young megaspores get separated from each other and the one to develop further gets surrounded by dense plasmodium and the non-functional ones move towards the periphery and disintegrate there (Fig. 7). A fully developed megaspore is yellowish brown in colour and completely shrivelled (Fig. 8).

The abortive megasporangia are much smaller than the functional ones. Therein the development proceeds in a normal fashion upto the archesporial stage. Further development fails to occur and absence of meiotic division 
was constantly observed. The disorganized cells of the archesporium lie embedded in scanty plasmodial mass and the sporangia appear hyaline (Fig. 9).

Microsporangia and microsporogenesis: A statistical analysis of 100 microsporocarps indicates that 45 per cent bear abortive microsporangia in contrast to 65 per cent of megasporocarps. Not even a solitary microsporocarp could be observed with all the microsporangia as functional and the maximum number of functional ones being 150 per sporocarp.

The earlier stages of microsporangial development are similar to those of megasporangium. The primary archesporial cell appears like a biconvex lens in a transection (Fig. 10) which undergoes three successive divisions to organize an eight-celled archesporium (Fig. 11). This is an important deviation from the sixteen-celled archesporium recorded earlier in other species of the genus, viz., S. natans (Yasui 1911) and S. cucullata (Deshpande 1943). Before the onset of meiosis the nucleus of the spore mother cells shifts towards the periphery due to vacuolization of cytoplasm on the opposite side (Fig. 12). The nucleus then enters meiosis which is highly abnormal. After the tetrad formation unequal, shrivelled microspores are formed (Fig. 13) whose number varies from sporangium to sporangium owing to differential behaviour of their spore mother cells. The plasmodium becomes frothy with large si-ed vacuoles and form a hardened massula.

Meiosis: The course of meiosis is identical in mega- and microsporangia. As pointed out earlier, before the beginning of meiosis the nucleus shifts towards one side of the cell. It is pertinent to recall comparable feature earlier recorded by Mehra and Loyal (l.c.) in a sterile, triploid race of Marsilea minuta. The earliest stage of meiosis analysed was late metaphase I at which the chromosomes were seen associated all the way ranging from bivalents to pentavalents and a high percentage of univalents was noticeable (Fig. 14). The data of metaphase analysis based on 20 exceptionally clear cells are given in Table 1.

A perusal of Table 1 shows that chromosome pairing varies a great deal and as such no single association perhaps represents their true homologies. Nevertheless, the presence of multivalents in all the cells examined is indicative of a high degree of homology between the parental genomes. At anaphase I there is a highly irregular separation of chromosomes and laggards were constantly observed at telophase I (Fig. 15) which get variously distributed in the cells. In about 20 per cent spore mother cells the divisions fail to proceed beyond telophase I and the spore mother cells develop walls and thus behave as monads. Due to the absence of well organized nucleus these monads degenerate (Figs. 16-18). In the rest of the spore mother cells the second division proceeds normally resulting in highly varying distribution of the chromosomes (Fig. 19). The tetrads were organized in about 40 per cent spore mother cells, but the 4 nuclei showed well marked difference in their size (Fig. 20). In Figs. 21 and 22 only 3 nuclei are seen with or without 

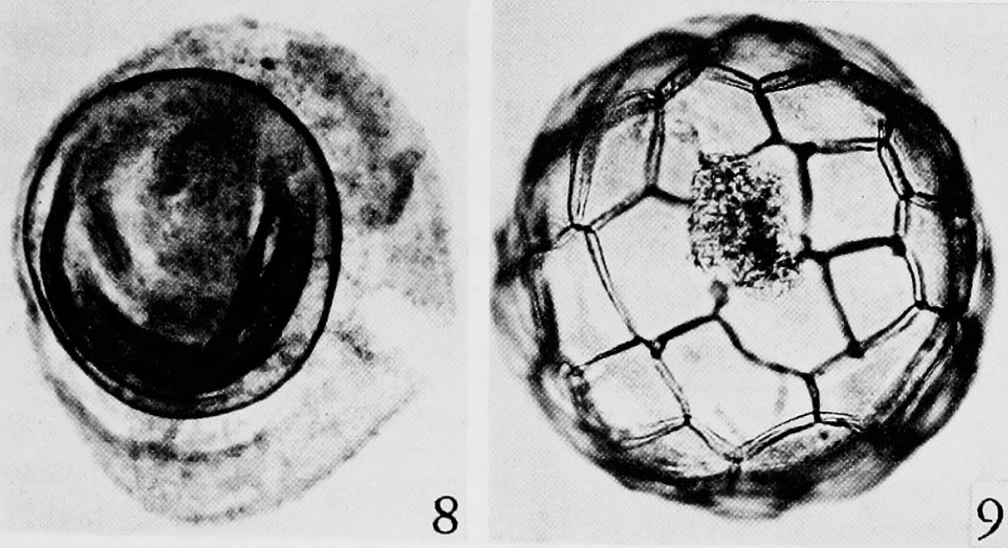

9

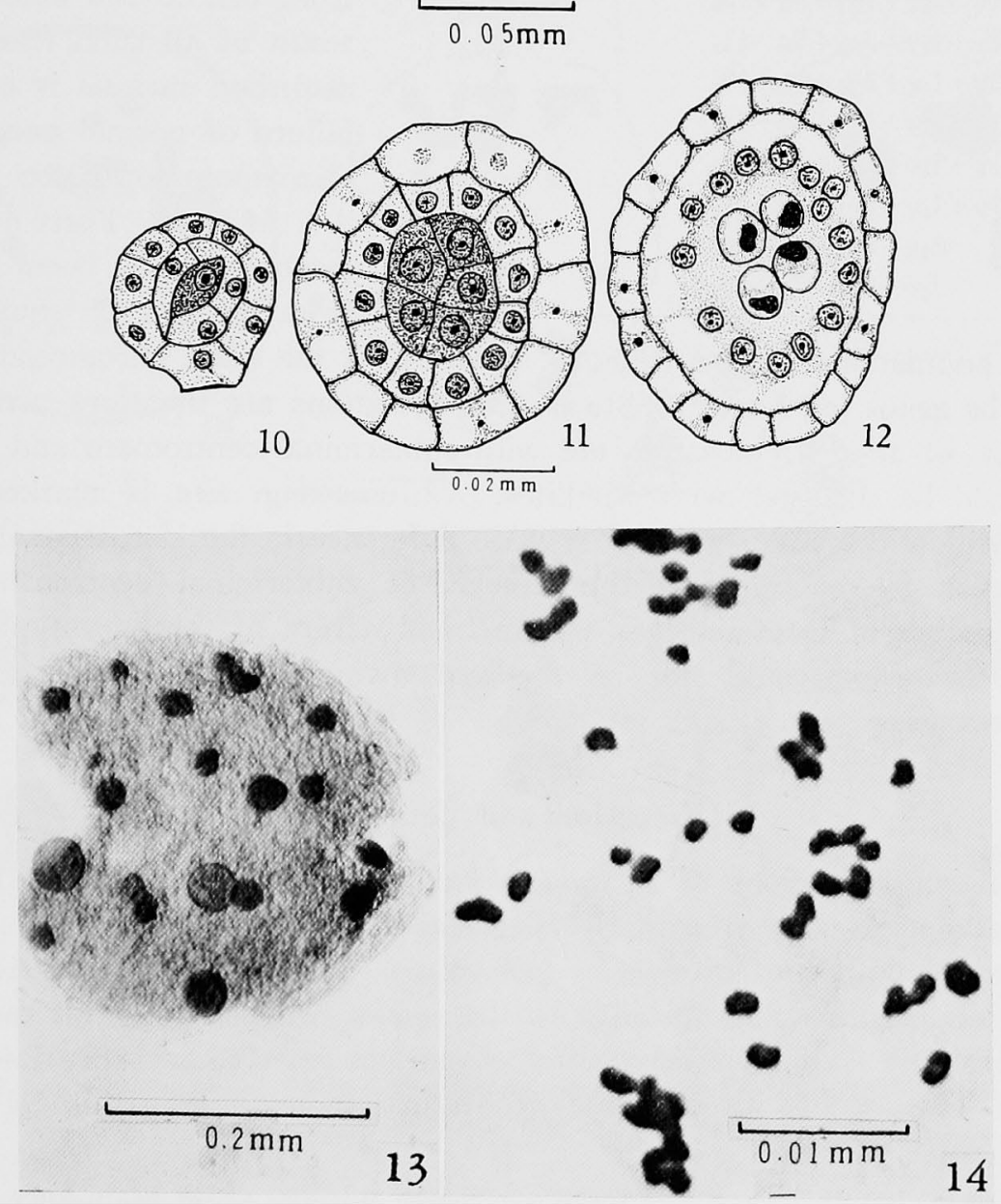

Figs. 8-14. 8, a shrivelled megaspore in a megasporangium. 9, an abortive, hyaline megasporangium with degenerated contents of the archesporium. 10, a young microsporangium showing archesporial cell surrounded by tapetal cells. 11, T.S. microsporangium showing eight-celled archesporium with only 5 cells visible in one plane. 12 , T.S. microsporangium showing spore mother cells with eccentric nuclei before the onset of meiosis. 13, a microsporangium showing unequal sized microspores. 14, late metaphase I showing multivalents and univalents. 
micronuclei. More than 4 nuclei plus a few micronuclei were also seen (Figs. 23, 24) and due to lack of cytokinesis in such cells polyads failed to arise and such monads, therefore, were comparable to those formed at the close of first division. The monads are thus formed in fairly large proportion and the cause of failure of cytokinesis is not readily understood. The monads loose stainability due to degeneration of their chromatic material.

Table 1. Pairing of chromosomes at late metaphase

\begin{tabular}{c|c}
\hline Associations & No. of cells \\
\hline $1_{\mathrm{V}}+1_{I V}+2_{I I I}+6_{I I}+18_{I}$ & 2 \\
$1_{V}+1_{I V}+4_{I I I}+4_{I I}+16_{I}$ & 4 \\
$1_{V}+2_{I V}+1_{I I I}+8_{I I}+13_{I}$ & 1 \\
$3 V+1_{I V}+3_{I I I}+3_{I I}+11_{I}$ & 3 \\
$2 V+1_{I V}+2_{I I I}+6_{I I}+13_{I}$ & 4 \\
$1_{V}+1_{I V}+4_{I I I}+5_{I I}+14_{I}$ & 1 \\
$1_{V}+3_{I V}+2_{I I I}+2_{I I}+18_{I}$ & 2 \\
$1_{V}+1_{I V}+2_{I I I}+8_{I I}+14_{I}$ & 1 \\
$3_{I V}+3_{I I I}+4_{I I}+16_{I}$ & 1 \\
$1_{I V}+3_{I I I}+7_{I I}+18_{I}$ & 1 \\
\hline
\end{tabular}

It is clear from the data presented that the formation of multivalent associations and the segregations of chromosomes is highly varying from cell to cell and the net result of all such features of disturbed meiosis is complete failure of normal mega- and microspore formation.

Mitosis: Forty five chromosomes have been counted from the leaf tip squashes in

all the populations studied (Fig 25). Since 9 is the basic chromosome number in the genus (cf. Loyal 1958), all the populations are therefore pentaploid. Majority of the chromosomes are with subterminal centromere and at least two could be detected with satellites. Chromosome size is markedly different within the complement. A wide difference in the size of smallest and the largest chromosomes and the presence of subterminal centromere in a large number of them indicate asymmetrical nature of the karyotype. This aspect, however, could not be finalized owing to very small size of the chromosomes.

\section{Discussion and conclusions}

All the populations of $S$. auriculata investigated comprise pentaploids which except for some quantitative differences exhibit complete uniformity of their morphology and cytological behaviour. The source of material under cultivation may in all probability be the same. Furthermore, all the plants fit well in the taxonomic description of the species (Baker 1886, De la Sota 1962). This, alongwith its wide occurrence indicate that this $5 x$ race is fairly old.

The occurrence of multivalents possibly implies close homology between the parental genomes and the present race appears to be intraspecific in origin, and may have arisen in either of the two ways. It may be a cross between a hexaploid and a tetraploid existing in the original home of this species. The second possibility is that there occur a diploid and a tetraploid. An unreduced spore from the latter will form a $4 \mathrm{x}$ gamete which after fusion 
with a haploid gamete of the diploid race will result in $5 \mathrm{x}$ individuals. That these races may have already been known under well recognized taxonomic species such as $S$. rotundifolia and $S$. herzogi which, as pointed out by $D e$ la Sota bear close morphological resemblance, cannot be ruled out. Cyto-
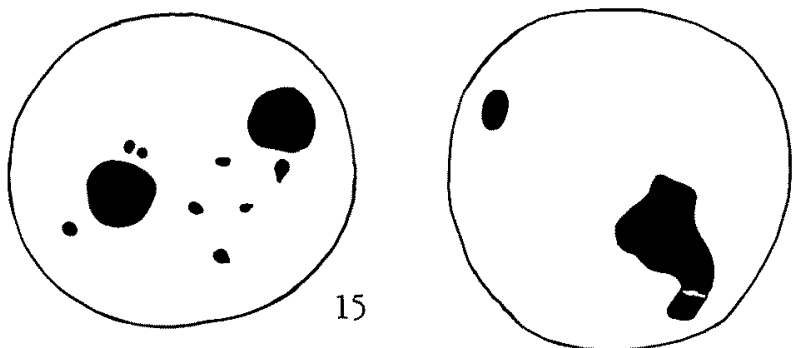

16
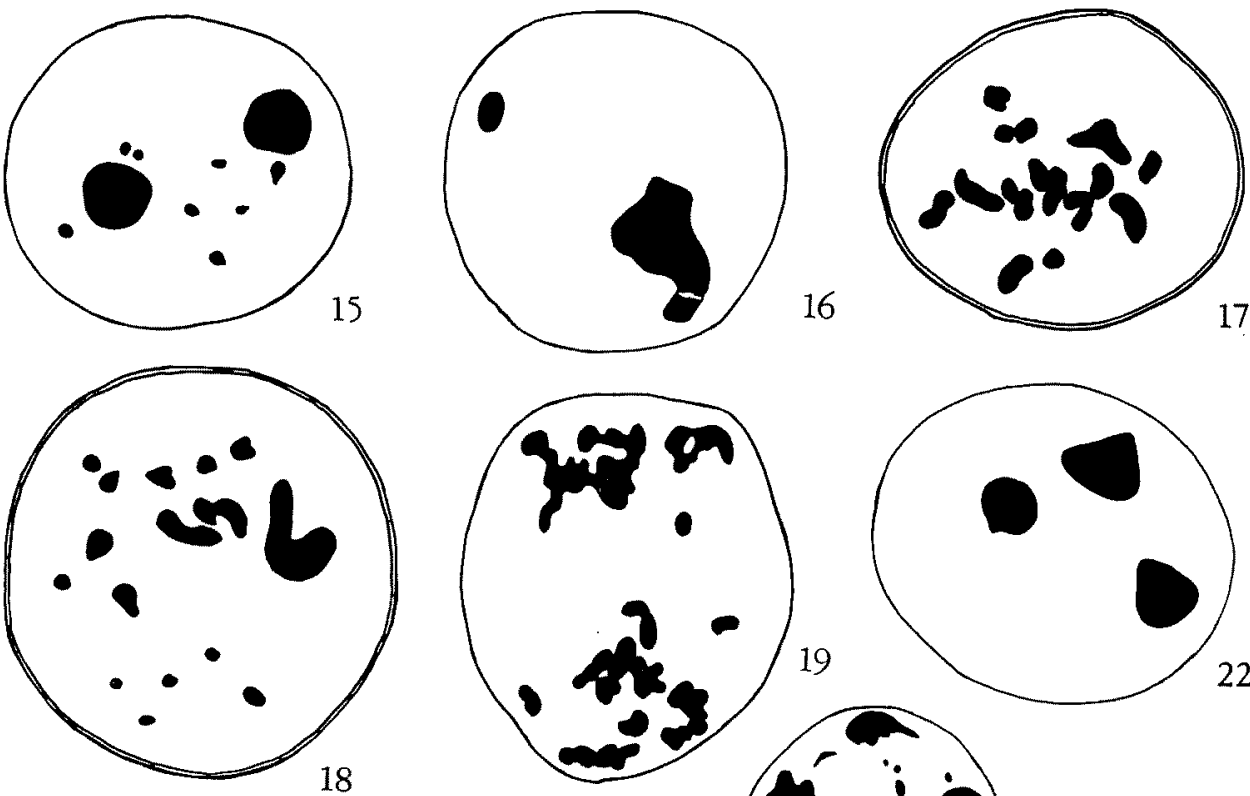

17
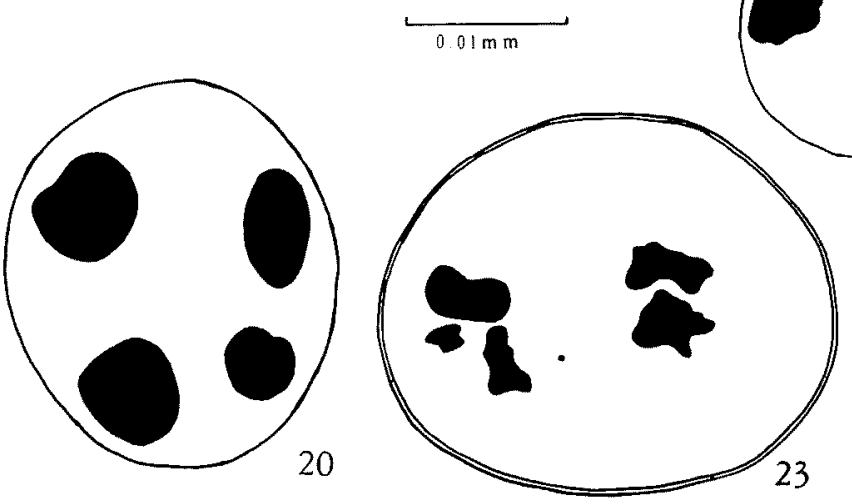

21

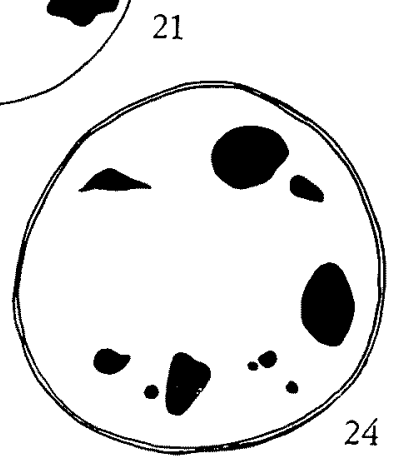

Figs. 15-24. 15, anaphase I with laggards. 16, telophase I with two highly unequal nuclei. 17-18, monads after the failure of second division. 19, spore mother cell showing abnormal anaphase II. 20, tetrad with a pair of bigger and a pair of smaller nuclei. 2122 , triads, only three nuclei with and without micronuclei. 23-24, monads at the close of sacond division showing more than 4 nuclei plus micronuclei.

logical data on allied sexual species, therefore, seem to possess key to the above intriguing problem.

The course of meiosis provides a convincing proof of complete lack of viable spores and sexuality. The events which lead to sterility are encountered at two different stages. Firstly, as shown in the main body of the paper, 
62 per cent and 45 per cent mega- and microsporocarps contain completely abortive sporangia whose contents degenerate before the onset of meiosis. The cause of degeneration is not vivid, nevertheless it seems genetically controlled because all the populations were affected. Secondly, in the functional sporangia the irregularities of meiosis are typical of pentaploids. The

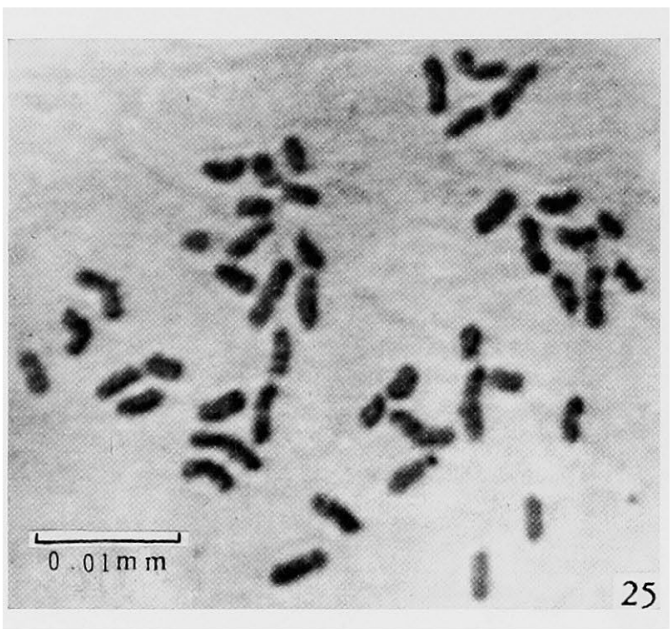

Fig. 25. Somatic metaphase from a leaf tip squash showing $2 \mathrm{n}=45$ chromosomes. formation of monads which lack well organized nucleus at the close of both the first and second divisions, was persistently observed. The failure to form well organized nucleus in monads occurs in a manner as if lack of directive force of the spindle is involved. This point needs a deeper probe.

The discovery of eight-celled archesporium in both mega- and microsporangia is of unusual interest and contrasts sharply with sixteen-celled microsporangium in $S$. natans and $S$. cucullata (cf. Yasui, 1.c., Deshpande, 1.c.). This situation led Mahabale and D'Mello (l.c.) to conclude that the present species has apogamous mode of reproduction, comparable to apogamous homosporous ferns. Bonnet (l.c.) while quoting the above authors used the term ' apospory'. It may be emphasized on the basis of present study that the reproductive mechanism inferred by the above authors is erroneous. Because, the eight celled archesporium is not analogous to that of an apogamous species wherein sequence of events leading to eight-celled archesporium is entirely different. Moreover, in apogamous ferns viable spores are regularly formed with zygotic chromosome number and their gametophytes behave apogamously. This was never observed in any of the populations studied by the writers.

In the complete absence of viable spores the present taxon has been preserved through effective means of vegetative reproduction and it spreads as an aggressive weed wherever large body of water becomes available (cf. Lake Kariba in Rhodesia, data supplied by Dr. D. S. Mitchell).

On the basis of cytological evidence accumulated thus far, it may be summed up that sterile races in heterosporous ferns (cf. triploid Marsilea minuta, Mehra and Loyal, 1.c.) get preserved and widely distributed by no other means except vegetative. On the other hand, in some homosporous fern genera with unbalanced genetic constitution (genic and'or chromosomal) in addition to vegetative reproduction by rhizomes, viable spores are formed which behave apogamously to complete the life cycle in the absence of sexual reproduction. 
Finally, it is suggested that cytological studies with modern techniques are of utmost importance and may be profitably applied in case of aberrant spore formation recorded in earlier literature (cf. Feller 1953, Boterberg 1956).

\section{Summary}

Salvinia auriculata Aublet under cultivation in several places in India and Rhodesia, S. Africa is pentaploid and show $2 n=45$ in leaf tip squashes. Analysis of mega- and microsporocarps reveals respectively 62 per cent and 45 per cent abortive sporangia in which meiosis fails to occur and archesporium degenerates. In the functional mega- and microsporangia the course of meiosis is typical of the pentaploids. A high percentage of spore mother cells show failure of cytokinesis both at the close of first and second division resulting in monads which lack well organized nucleus. The above alongwith other irregularities of meiosis offset normal spore formation, completely.

The presence of multivalents indicates homology between the parental genomes to a fair degree. On this basis intraspecific origin of the present taxon is surmised.

The archesporium is eight-celled in both the types of sporangia. A reference to previous literature especially Mahabale and D'Mello (1952) shows that on this criterion apogamous reproduction was inferred. It is discussed that the eight-celled archesporium is not indicative of apogamy since other features of apogamy that follow eight-celled archesporium are totally lacking. Finally the role of vegetative apomixis in preserving sterile races of heterosporous ferns is discussed.

Acknowledgments: We are deeply indebted to Prof. P. N. Mehra for his valuable advice and encouragement. To Dr. T. N. Bhardwaja for translating some literature in French and Drs: D. S. Mitchell (Rhodesia), De la Sota (Argentina) and A. S. Mehta (Patna) for sending us material and literature, we wish to record our deep sense of gratitude.

\section{References}

Baker, J. C. 1886. A synopsis of the Rhizocarpeae. Jour. Bot. Brit. and For. 24: 97-101. Bonnet, A. L. M. 1955. Contribution a l'étude des Hydropterides. Recherches sur Salvinia auriculata Aubl. Ann. des Sci. nat. Bot. 11: 529-600.

Boterberg, A. 1956. Etudes sur les Hydropteridales-IV Gense et differenciation de parois sporales chez Marsilea diffusa Lepr. La cellule, tom 43, vol. 1: 81-106.

De la Sota, E. R. 1962. Contribucion al conocimiento de Las 'Salviniaceae' Neotropicales. I Salvinia oblongifolia Martius II. S. auriculata Aublet. III. S. herzogii Nov. Sp. De Darwiniana 12: 465-520.

Deshpande, J. V. 1943. A study of the sporophyte of Salvinia cucullata Roxb. Jour. Indian Bot. Soc. 22: 59-84.

Feller, M. J. 1953. Etudes sur les Hydropteridales II. Sporocarp et sporogense chez Marsilea hirsuta, R. Br. La Cellule 45: 307-377.

Loyal, D. S. 1958. Cytology of two species of Salviniaceae. Curr. Sci. 27: 357-358.

- 1962. Abnormal sporelings of Regnellidium diphyllum Lindm. and chromosome number of the genus. Res. Bull. Panjab Univ. 13: 25-30. 
- and Grewal, R. K. 1964. Cytological approach to the life history of Salvinia auriculata Aublet. Curr. Sci. 33: 344-346.

Mahabale, T. S. and D'Mello, J. 1952. Apogamy in Salvinia. Curr. Sci. 21: 227-228.

Mehra, P. N. and Loyal, D. S. 1959. Cytological studies in Marsilea with particular reference to $M$. minuta L. Res. Bull. Panjab Univ. (N.S.) 10: 357-374.

Yasui, K. 1911. On the life history of Salvinia natans. Ann. Bot. 25: 469-483. 